\title{
Misiunea preotului \\ după exemplul Sfântului Ioan Gură de Aur
}

\section{Cristi Adrian CRISTESCU}

Abstract: Priesthood is a continuation of the mission of Jesus Christ in this world, and this holy duty must awake much more clerical consciousness. We have a lots of priests having such an alive consciousness but, it seems, none like Saint John's Chrysostom . During the 12 years as a priest in the Antiohia's Church, he leed an intense pastoral and missionary activity by praying, preaching, writing and by taking care always of poor people and mankind generally. The famous convention "About Priesthood" shows us the greatest responsibilities,by representingthe source of inspiration of many clerics in their holy mission. Saint John Chrysostom remains a model of vocation and sacrifice of the orthodox priest, able to understand the pain of the nearones and to be permanently placed in the service of the people and to whom all the clerics need to have it as a model.

Keywords: priest, church, poors, mission, society. 


\section{Preotul este aducătorul de pace pe pământ}

Preoția este continuarea învățăturii Mântuitorului Hristos în această lume, în care dezorientarea şi lipsa de respect pentru persoana umană se ridică la cel mai înalt nivel. Societatea nu poate răspunde la toate problemele omului contemporan sau dacă răspunde o face întrun mod nedeplin, nemulțumindu-1 pentru că nu-i aduce fericirea pe care acesta o caută.

Omul nu reprezintă o mașină cu care societatea se poate ,juca” schimbând legi de pe o zi pe alta, ci el este „,chipul și asemănarea lui Dumnezeu", adică are un suflet care caută ceva ce depăşeşte ceea ce-i poate oferi societatea. Acest ceva este pacea și liniștea lui Hristos, oferită de preot în primul rând prin harul Sfintelor Taine și apoi prin împreună lucrarea noastră cu harul lui Hristos.

Un astfel de preot exemplu îl avem pe Sfântul Ioan Gură de Aur, care ,este unul dintre sfinții cei mai puternici și mai vii duhovnicește din câți au răsărit și au înflorit în ogorul Bisericii. Viaţa, faptele şi scrierile lui s-au realizat la cea mai înaltă dimensiune spirituală de care e capabil un om și un preot deosebit"'. El întotdeauna încerca să fie mai presus decât orice om, aşa cum sfătuieşte în tratatul „,Despre preoţie”: „Să fie aduşi la preoţie aceia care întrec cu mult pe ceilalţi, şi care sunt cu atât mai presus de ceilalţi, în ce priveşte virtutea sufletului lor, cu cât era Saul, prin mărimea corpului său, mai presus de întregul popor al evreilor, şi chiar cu mult mai mult decât atât”’.

\footnotetext{
${ }^{1}$ Ioan G. Coman, Despre Sfântul Ioan Gură de Aur, Studii, București, Edit. Basilica, 2015, p.19.

${ }^{2}$ Sf. Ioan Gură de Aur, Despre preoție, trad. de Dumitru Fecioru, introducere de Policarp Pîrvuloiu, București, Edit. Basilica, 2015, p. 83-84.
} 


\section{Calităţile morale ale preotului, după Sfântul Ioan Gură de Aur}

Deși a trăit în secolele III-IV, învățătura Sfântului Ioan Gură de Aur este de mare actualitate atât pentru preoții cât și pentru credincioșii zilelor noastre, deoarece la baza ei a stat harul lui Dumnezeu Cel pururea neschimbător. Părintele profesor Ioan Coman ne spune că la Sfântul Ioan „Pastorația este expresia practică a sufletului preotului pentru sufletele credincioșilor" ș și ne arată care sunt factorii pastorației sale: dragostea, curăția, munca, entuziasmul și jertfa ${ }^{4}$. Dacă acești factori nu sunt folosiți până la ultima strădanie a preotului, atunci preoția sa nu se poate realiza în sensul său duhovnicesc.

Dragostea preotului trebuie să fie una exemplară și devotată pentru credincioșii săi.

„Dacă noi socotim râvna unor oameni pe care-i vedem că poartă grijă de slugile și de vitele noastre ca un semn al dragostei lor pentru noi, deși pe toate acestea le avem cu bani, ce trebuie să spunem de răsplata mare pe care o va da Hristos păstorilor turmei Sale celei cuvântătoare, pe care a cumpărat-o nu cu bani, nici cu ceva asemănător, ci cu propria Sa moarte, și Și-a dat sângele Său ca preț al turmei Sale?’’

Dragostea păstorului pentru „turma sa” este împărtășită din dragostea lui Hristos pentru Biserica Sa, de aceea Hristos îl întreabă pe Petru dacă-L iubește, nu pentru a se încredința Domnul de dragostea lui, ci pentru a arăta dragostea Sa supremă pentru oamenii lăsați în grija păstorului lor sufletesc ${ }^{6}$. Mântuitorul 1-ar fi putut

${ }^{3}$ Ioan G. Coman, op.cit., p. 55.

${ }^{4}$ Ibidem, p. 56.

${ }^{5}$ Sf. Ioan Gură de Aur, op.cit., p. 80.

${ }^{6}$ Sfântul Ioan spune că ,,sufletul preotului trebuie să fie ca o lumină care strălucește peste tot pământul. Sufletul nostru este înconjurat de întunericul atât de gros al conştiinţei rele, încât el e acoperit din ce în ce mai mult şi nu-I este cu 
întreba pe Petru „Petre, dacă Mă iubești, ține post, culcă-te pe pământ gol, priveghează îndelung, vino în ajutorul celor nedreptățiți, fii tatăl orfanilor, sprijinitorul văduvelor! Așa însă le-a lăsat la o parte pe toate acestea, și ce i-a spus? Atât: «(Paște oile Mele!»»”.

Curăția ${ }^{8}$ la care îndeamnă Sfântul Ioan pe preoți este de o măsură ireproșabilă și arată importanța slujirii preoțești în orice perioadă a societății:

„când un împărat îi dă unuia dintre supușii săi cinstea aceasta de a închide și de a elibera din închisoare pe cine vrea, cinstea dată lui îl face cu vază înaintea tuturor și demn de invidiat; dar, când Dumnezeu îi dă preotului o putere cu atât mai mare cu cât este mai de preț cerul decât pământul și sufletul decât trupul, cum poate să li se pară unora că preoția este o slujbă atât de neînsemnată...?’’’

Harul lui Dumnezeu se lasă aşezat numai într-un suflet curat, de

putinţă să privească liber pe Stăpânul său. Preoții sunt sarea pământului. Cine ar putea răbda mai uşor nebunia şi lipsa noastră de experienţă decât voi, preoţii, care sunteţi obişnuiţi să ne iubiţi peste măsură?’'(Sf. Ioan Gură de Aur, Despre preoţie, trad. de Dumitru Fecioru, introducere de Policarp Pîrvuloiu, București, Edit. Basilica, 2015, p. 213-214).

${ }^{7}$ Ibidem, p. 83.

${ }^{8}$ De remarcat la Sfântul Ioan este faptul că cere preotului o pregătire continuă pentru că el poartă un război neîntrerupt: „Se cuvine ca preotul să fie nu numai curat, aşa cum se impune într-o asemenea slujire, dar şi foarte priceput şi încercat în multe lucruri, cunoscând cele ale vieţii la fel cu cei ce sunt prinşi în valurile ei, şi, totuşi, dezbrăcat de ele mai mult ca monahii care locuiesc în munţi. Deoarece preotul trebuie să fie în legătură cu bărbaţi care au soţii, care cresc copii, care au servitori, care sunt încărcaţi de bogăţii, care au servicii publice, care sunt învestiţi cu magistraturi, se cuvine ca el să fie înzestrat; zic felurit înzestrat, dar nu viclean, nu adulator, nu ipocrit, ci plin de multă afabilitate şi bună credinţă, ştiind să modereze în chip folositor, atunci când împrejurarea o cere; să fie bun şi sever în acelaşi timp" (Sf. Ioan Gură de Aur, Despre preoţie, trad. de Dumitru Fecioru, introducere de Policarp Pîrvuloiu, București, Edit. Basilica, 2015, p. 214).

${ }^{9}$ Ibidem, p. 110. 
aceea preotul trebuie să alunge în primul rând răul de la sine şi apoi răul de la păstoriţii săi.

Munca preotului atunci când este pusă în atmosfera sfinţeniei şi a dragostei, îl înalţă pe slujitorul lui Dumnezeu spre culmile cele mai înalte ale vieţii preoţeşti, făcându-1 model pentru sufletele păstorite. Un astfel de model era Sfântul Ioan Gură de Aur care slujea, predica, medita, catehiza, cerceta pe săraci, citea şi scria fără încetare şi cu truda şi puterea unui om perfect sănătos, deşi el era firav şi deseori bolnav.

Din această râvnă a Sfântului Ioan, fiecare preot al zilelor noastre trebuie să se adape mai ales în momentele grele când deznădejdea ${ }^{10}$, lipsa de curaj şi dezorientarea îşi spun cuvântul tot mai mult. Deci Sfântul Ioan este exemplul preotului neobosit, care simte ajutorul lui Dumnezeu atotprezent în viaţa sa şi care face posibilă rodirea credinţei, chiar şi în cele mai întunecate timpuri ale istoriei.

Entuziasmul şi jertfa alesului lui Dumnezeu, scoate în evidenţă caracterul sfânt al misiunii sale care poate merge chiar până la martiriu, aşa cum reiese din viaţa Sfântul Ioan.

Dar astăzi nimeni nu cere sacrificiul până la moarte al preotului, ci lupta pentru adevăr, credinţă şi dragoste să depăşească barierele timpului şi ale puterii de sine, ridicând preoţia la piedestalul cel mai înalt care este Hristos. „Preoţia hrisostomică este un eroism şi un martiriu. Ea continuă cu măreţie preoţia Mântuitorului Hristos şi a Sfinţilor Apostoli" "1.

\footnotetext{
${ }^{10}$ Părintele Profesor Ioan G. Coman ne atrage atenţia că „lucrul cel mai uimitor e că în timpul celor trei ani de exil (404-407), el a desfăşurat în condiţiile unui trist prizonierat o activitate pastorală şi misionară deosebită. Documentele care reflectă viaţa lui din această vreme ni-l prezintă tot aşa de entuziast şi de încordat ca în vremurile bune de la Antiohia şi Constantinopol. El ştia că exilul îi va aduce moartea de la o zi la alta, dar tocmai pentru aceasta lucrarea lui evanghelică nu trebuia să înceteze."( Ioan G. Coman, Despre Sfântul Ioan Gură de Aur, Studii, București, Edit. Basilica, 2015, p. 57).
}

${ }^{11}$ Ibidem, p. 57. 
Astfel nu putem uita că lupta preotului pentru valorile menţionate are o mare influenţă asupra turmei sale, pentru a-i ridica pe aceştia la înălţimea convingerilor sale morale. Adică Sfântul Ioan este înainte de toate un moralist practic al învăţăturilor evanghelice ${ }^{12}$, iar rolul său era să ,îndrepte moravurile decăzute ale societăţii vremii sale" $" 13$.

\section{Lucrarea preotului în parohia sa}

Ne punem întrebarea în ce ar putea să conste, mai exact, lucrarea preotului în parohia sa, în aceste vremuri în care libertatea este greşit înţeleasă şi personalitatea umană este dornică de remarcat, iar concurenţa dintre persoane este din ce în ce mai puternică? Ce tact pastoral ar trebui să abordeze păstorul pentru a face pe deplin înţeles mesajul său?

Răspunsul ni-1 arată Sfântul Ioan Hrisostom prin întrebuinţarea nesfârşită a cuvântului virtute, în tratatul său „Despre preoţie”, unde se împletesc cele mai înalte virtuţi morale:

„Dacă cei ce fac eforturi în vederea unei performanţe atletice au nevoie de medici, de maeştri de gimnastică, de o dietă scrupuloasă, de exerciţ̧ii şi de o nesfârşită supraveghere (o neglijență cât de mică răstoarnă şi distruge totul), cei care au primit în îngrijire corpul lui Hristos, corp care are a lupta nu contra corpurilor, ci contra puterilor nevăzute, cum vor putea ei să păstreze acest corp cast şi sănătos, dacă nu depăşesc cu mult virtutea omenească şi nu cunosc întregul tratament folositor sufletului" ${ }^{\prime 14}$.

În primul rând preotul să fie un bun slujitor al altarului lui Hristos, în sensul de a contribui la sfinţirea lumii prin invocarea

\footnotetext{
${ }^{12}$ Ibidem, p. 58.

${ }^{13}$ Ibidem, p. 59.

${ }^{14}$ Sf. Ioan Gură de Aur, op. cit., p. 168.
} 
Duhului Sfânt atât prin rugăciunea comună în Biserică, cât şi prin rugăciunea personală. Credincioşii să simtă climatul comuniunii sfinţitoare atunci când se roagă în Biserică, alături de preot, dar mai ales în mod desăvârşit atunci când primesc Sfânta Împărtăşanie ${ }^{15}$.

Astăzi sentimentul de unitate este din ce în ce mai pierdut din conştiinţa oamenilor, făcând loc individualismului, în care termenul de persoană pierde teren în detrimentul celui de individ. Preotul are datoria de a trezi aceste conştiinţe adormite pentru a forma o societate cât mai vie duhovniceşte şi care să simtă că are valoare de veşnicie.

Trezirea de conştiinţe implică activarea chipului lui Dumnezeu din fiecare persoană umană. Acest lucru este mai ales lucrarea intimă a harului lui Dumnezeu, invocat în mod special prin preot, dar şi în mod personal prin străduinţa credinciosului.

În al doilea rând preotul să aibă conştiinţa de păstor al Bisericii lui Hristos aşa cum a avut-o Sfântul Ioan Gură de Aur. Tratatul

${ }^{15}$ Sfântul Ioan ne spune că: „Pâinea pe care o rupem nu este ea comuniune cu trupul lui Hristos? De ce Pavel n-a zis participare? Pentru că el a vrut să dea faptului o semnificaţie mai mare şi să arate marea legătură de unire. Căci prin participare noi numai ne împărtăşim cu trupul lui Hristos, în timp ce prin unire noi suntem în comuniune cu El...După cum acest trup se uneşte cu Hristos, tot astfel noi ne unim cu El prin această pâine. Dar de ce Pavel a adăugat: $<<$ (Pâinea) pe care noi o frângem ?>> E ceea ce se poate vedea întâmplându-se în Euharistie, nu pe cruce, unde se petrece contrariul... .Dar ceea ce El nu a suferit pe cruce suferă în producerea pentru tine şi rabdă ca să fie frânt pentru a-i umple pe toţi”" (Sf. Ioan Gură de Aur, Omilia XXIV, 2 la Epistola către Corinteni, în PG LXI, col. 200, apud Ioan G. Coman, Despre Sfântul Ioan Gură de Aur, Studii, București, Edit. Basilica, 2015, p. 176). Mai departe spune Sfântul Ioan: „Când vezi acest trup (al lui Hristos) întins în faţa ta, spuneţi: Datorită acestui trup nu mai sunt eu pământ şi cenuşă, nici rob, ci liber; datorită lui îmi pui nădejdea în ceruri şi voi primi bunurile de acolo, viaţa nemuritoare, soarta îngerilor, legătura strânsă cu Hristos. Moartea n-a putut să rabde acest trup ţintuit şi biciuit... .El, acest trup însângerat şi străpuns de lance, a făcut să curgă izvoare mântuitoare, unul de sânge şi celălalt de apă, pentru toată lumea" (Omilia XXIV, 2 la Epistola I către Corinteni, în PG LXI, col. 203, apud Ioan G. Coman, Despre Sfântul Ioan Gură de Aur, Studii, București, Edit. Basilica, 2015, p. 192). 
„Despre preoţie” arată calităţile spirituale ale păstorului sufletesc: „vocaţie, sfinţenie, evlavie, cultură multilaterală, râvnă pentru bine, dragoste de Hristos şi de oameni, tact în opera pastorală"’'

A treia calitatea a preotului, luând ca exemplul pe Sfântul Ioan Gură de Aur, este aceea de a fi un predicator atent şi neobosit:

„Predica mă însănătoşeşte. Cum deschid gura, mi-a trecut toată oboseala; cum încep să învăţ, dispare toată slăbiciunea. Nici boala, nici mii de alte piedici nu mă pot despărţi de dragostea voastră. Aşa cum vouă vă e foame să mă ascultaţi, aşa mie mi-e foame să predic. Adunarea voastră este cununa mea de glorie şi fiecare dintre voi care mă ascultă valorează cât tot restul oraşului'”'17.

Predicatorul trebuie să pregătească întotdeauna predica sa, neurmărind etalarea talentului său oratoric ci să caute, prin predica sa, aducerea la credinţă a celor care îl ascultă ${ }^{18}$.

Putem rezuma că lucrarea preotului în parohie trebuie să împlinească, din toată silinţa sa, toate cele trei aspecte ale preoţiei: de slujitor, de păstor şi de predicator.

\section{Concluzii}

Sfântul Ioan Gură de Aur rămâne modelul de referinţă al oricărui preot pentru succesul în misiunea sa, indiferent de contextul în care acesta propovăduieşte învăţătura Mântuitorului Hristos. Din viaţa

${ }^{16}$ Ioan G. Coman, Despre Sfântul Ioan Gură de Aur, Studii, București, Edit. Basilica, 2015, p. 143. Tot aici se spune: „Ca preot şi episcop, el s-a dovedit plin de nemărginită grijă şi dragoste pentru credincioşi şi pentru Biserică. El n-a dezminţit niciodată prin faptele sale principiile şi obligaţiile adevăratei preoţii”" ${ }^{17} \mathrm{Sf}$. Ioan Gură de Aur, Omilia după cutremurul de pământ, în PG 50, col.713714, apud Ioan G. Coman, Despre Sfântul Ioan Gură de Aur, Studii, București, Edit. Basilica, 2015, p.147.

${ }^{18}$ Ibidem, p. 148. 
exemplară a Sfântului Ioan se poate hrăni preotul în orice moment al vieţii sale. Trăind într-o societate în care căderile duhovniceşti ale oamenilor sunt din ce în ce mai prezente, preotul are misiunea de a face o lume mai bună, mai sănătoasă spiritual şi moral. Aceasta nu este un lucru deloc uşor, dar speranţa că va reuşi numai cerând ajutorul harului lui Dumnezeu, nu trebuie să-l părăsească.

Lumea va fi mai bună atunci când preotul lucrează în mod personal cu fiecare persoană care alcătuieşte familia încredinţată spre păstorire. Lucrarea aceasta va fi mai rodnică şi mai folositoare numai prin prezența Tainei Sfintei Spovedanii. Considerăm că lucrarea cea mai eficientă a preotului este atunci când discută cu omul şi-l face să creadă că are valoare personală, unică şi irepetabilă. Acest lucru are mai mult efect decât orice predică ţinută în Biserică şi care de cele mai multe ori poate plictisi.

Luând ca exemplu pe Sfântul Ioan Hrisostom, misiunea preotului în parohie poate avea un real succes în măsura în care acesta reuşeşte să-şi însuşească cât mai multe calităţi în persoana sa. Trăsătura care le desăvârşeşte pe toate este aceea de a avea dragoste neîncetată faţă de lume şi de popor, atât în momente de bucurie cât şi în momente de tristeţe. Dragostea nu trebuie să înceteze niciodată din firea preotului dornic de a o împărtăşi enoriaşilor săi. Dragostea este calitatea supremă care-1 pune în evidență pe păstorul cel adevărat, „care-şi pune sufletul pentru oile sale” (Ioan X, 11).

Sfântul Ioan Hrisostom rămâne modelul preotului capabil să dea răspuns la toate problemele societăţii vremii sale, iar învăţătura sa nu este una veche şi fără de folos, ci dimpotrivă, ea, dacă este urmată cu rigurozitatea hrisostomică, poate face o lume mai bună şi mai sănătoasă din punct de vedere moral şi spiritual, rămânând actuală pentru orice tip de societate. 


\section{Bibliografie}

1. ***Viaţa Sfântului Ioan Gură de Aur, în relatările istoricilor bisericeşti:Paladie, Teodor al Trimitundei, Socrates, Sozomen şi Fer. Teodor al Cirului, traducere din limba greacă, introducere şi note de Constantin Corniţescu, Bucureşti, Editura Institutului Biblic şi de Misiune al Bisericii Ortodoxe Române, 2001.

2. Coman, Ioan, Despre Sfântul Ioan Gură de Aur, Studii, Bucureşti, Editura Basilica, 2015.

3. Mordasov, Valentin, Sfaturile unui preot pentru enoriaşii lui, traducere din limba rusă de Mariana Caşu, Bucureşti, Sophia, 2015.

4. Sf. Ioan Gură de Aur, Despre desfătarea celor viitoare. Să nu deznădăjduim. Nouă cuvântări la Cartea Facerii, traducere din limba greacă veche şi note de Dumitru Fecioru, Bucureşti, Editura Institutului Biblic şi de Misiune al Bisericii Ortodoxe Române, 2008.

5. Sf. Ioan Gură de Aur, Despre preoţie, traducere din limba greacă veche de Dumitru Fecioru, introducere de Policarp Pîrvuloiu, Bucureşti, Editura Basilica, 2015. 